\title{
BULK DENSITY OF CHOPPED WHEAT STRAW - INFLUENCE OF MOISTURE CONTENT, FINE FRACTION CONTENT AND COEFFICIENT OF COMPACTION
}

\author{
Gennadii Golub $^{1}$, Nataliya Tsyvenkova ${ }^{1,2}$, Viacheslav Chuba ${ }^{1}$, Yaroslav Yarosh ${ }^{2}$ \\ ${ }^{1}$ National University of Life and Environmental Sciences of Ukraine, Ukraine; ${ }^{2}$ Zhytomyr National \\ Agroecological University, Ukraine \\ gagolub@ukr.net, nataliyatsyvenkova@gmail.com,vvchuba@ukr.net,yaroslav.yarosh76@gmail.com
}

\begin{abstract}
Quantity and quality of producer gas, received from 1 kilogram of a fine dispersed plant raw material, depends greatly from its bulk density. Bulk density influences aerodynamic processes that take place in a layer of this material. A design of equipment for compacting plant raw material has been presented. A poly-fractional mixture of chopped wheat straw is used as a raw material. The investigation is done by the method of multifactor experiment, where the moisture content in the raw material, fine fraction content in the poly-fractional mixture of chopped wheat straw and its coefficient of compaction are variable factors. Based on the received data, response surfaces were built. The experimental results let define the optimal ranges of each parameter to provide the rational bulk density value, that provides the highest producer gas calorific value $-11.1 \mathrm{MJ} \cdot \mathrm{m}^{-3}$. The obtained measurement results are in high correlation with the calculations. It was found that at the fine fraction content $50 \%$ in a poly-fractional mixture, the coefficient of compaction 1.4 and moisture content less than $20 \%$ bulk density is $200-250 \mathrm{~kg} \cdot \mathrm{m}^{-3}$. For that bulk density value the porousity coefficient is $0.54-0.61$ that provides the best conditions for heat and mass exchange processes in energy production from poly-fractional mixtures of chopped wheat straw. The results let understand that it is possible to manage the gasification process and receive high values of the gasifier specific thermal productivity while changing the raw material bulk density. Using the obtained results the new laboratory practice for students of engineering courses was prepared and successfully tested.
\end{abstract}

Keywords: raw material, mixture, porousity, pelleting.

\section{Introduction}

Lectures on the disciplines "Designing and calculation of technological systems in horticulture", "Machines and equipment for biotechnologies" and "Methodology and technology of scientific investigations" include all fundamental engineering technologies, namely: bioenergetic systems [1], technological processes in bioenergetic complex [1;2],designing and producing machines and equipment for bioenergetics [3], exploitation of machines and equipment [3; 4], ensuring reliability and longevity of machines and equipment in bioenergetics [3; 4]. Master degree students study methods, technology and organization of scientific and investigation activities in the abovementioned direction, prepare reports about scientific work, reviews, scientific papers.

Lectures are completed by the themes carried out in practice, namely, the technological process of recieving biofuel of plant raw material for energy production [5], production and usage of biodiesel [6; 7], biogas [8], producer gas [9], quality control of a received energy carrier [6], technological tests [10], operation of equipment working on alternative energy [11], production of energy of alternative energy carriers [12], etc. Students have an electronic form of educational and training materials on the university web [13] at their disposal, beside their own notes from lectures, for studying.

Preparation of plant raw material is a fundamental operation of the biofuel production technology [3] and receiving energy on its basis [5]. When exploring technologies of direct burning of raw material and its gasification, one of the main fuel-technologic characteristics, alongside with the moisture content, tar, sulphur content, ash capability, windage, ability to sintering, is its volumetric calorific value [14]. To raise the volumetric calorific value of plant raw materials, technological operations like chopping and compaction are used [5; 14].

When studying the disciplines: "Machines and equipment for biotechnologies" and "Designing machines and equipment for bioenergetics", students design and take part in investigation of operational parameters of equipment for briquetting and granulation of plant raw materials. The effectiveness of compaction, when using different types of equipment, is studied in practices. For example, when using the abovementioned equipment, it is possible to raise the straw calorific value from $14.25 \mathrm{MJ} \cdot \mathrm{kg}^{-3}$ - when not chopped to $16.5-18.8 \mathrm{MJ} \cdot \mathrm{kg}^{-3}$ - in form of pellets and briquettes.

Next, we deal with processes of converting the prepared plant raw material into energy, namely: thermal, mechanical and electrical. Production of thermal energy is mostly reviewed, when studying 
direct burning of raw material $[3 ; 5]$, thermal, mechanical and electrical - when studying gasification technologies $[3 ; 5 ; 15]$.

Both technologies have their flaws and advantages $[3 ; 5]$. However, with direct burning plant raw material, particularly straw, in boilers, as well as gasifying it students meet some negative factors. Among them are: ash-slag agglomerates formation $[8 ; 12 ; 16]$, corrosive wear of equipment [4], periodical pattern of receiving heat (gas) and presence of mechanical and chemical incompleteness of combustion without propper raw material pretreament $[3 ; 5 ; 17]$. Students and teachers are looking for the ways of solving these problems together.

Students also do scientific investigatons in chosen directions by themselves in form of master thesis on speciality "Agroengineering". These theses match the modern level of science progress, and their topics are relevant.

In the process of studying the discipline "Methodology and technology of scientific investigations" students investigate combined influence of physical and chemical properties of raw material on quality of biofuels on its base, as well as the dependence of the quality and quantity of the received energy on the raw material pretreatment method.

The goal of this work is to determine the influence of the fine fraction content $R_{f}$, moisture content $W^{p}$ and the coefficient of compaction $k$ on the bulk density $\rho$ of a poly-fractional mixture of chopped straw by the method of multifactor experiment.

\section{Materials and methods}

Ground wheat straw was used as vegetable raw material. The chemical composition of straw by dry mass is: $\mathrm{C}=44.43 \%, \mathrm{~N}=0.52 \%, \mathrm{O}=44.43 \%, \mathrm{H}=5.86 \%, \mathrm{~S}=0.11 \%$, cinder content is about $6.5 \%$. On its base a poly-fractional mixture was made. The composition of the mixure is: small splintered stems $\sim 8 \mathrm{~mm}$ long, wall thickness $0.15 \mathrm{~mm}$; bigger splintered stems $10-30 \mathrm{~mm}$ long, wall thickness $0.15-0.25 \mathrm{~mm}$; squished stems $20-40 \mathrm{~mm}$ long, wall thickness $0.3-0.5 \mathrm{~mm}$; cylindrical even stems $15-35 \mathrm{~mm}$ long, wall thickness $0.2-0.3 \mathrm{~mm}$, outer diameter $2-4 \mathrm{~mm}$; cylindrical stems $\sim 35 \mathrm{~mm}$ long with nubs, wall thickness $0.5-1.1 \mathrm{~mm}$; all other fractions content less than $3 \%$.

To compact the chopped straw mixture special equipment was developed, Fig. 1.

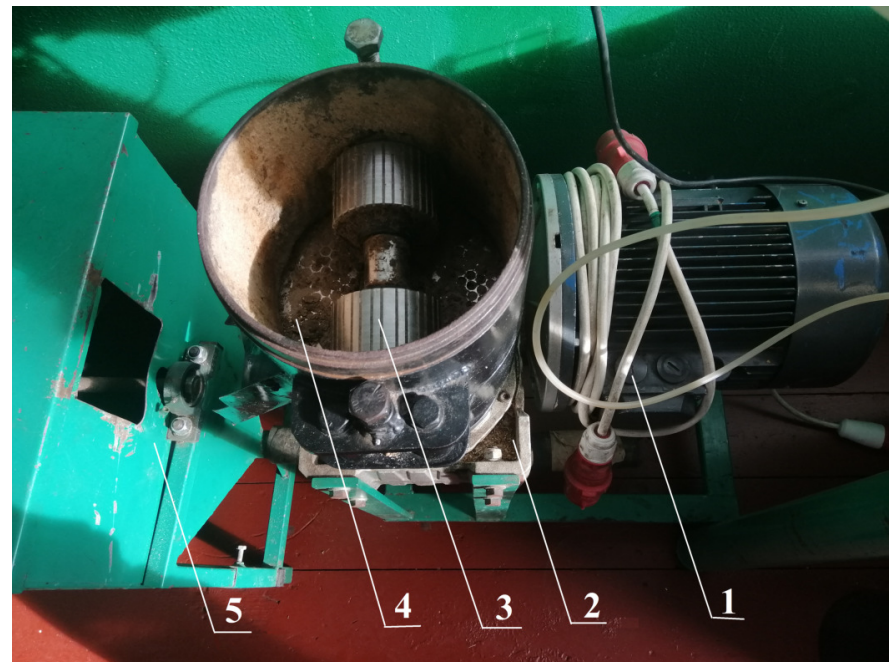

Fig. 1. Experimental equipment: 1 - electric motor; 2 - drivetrain; 3 - pressing rollers; 4 - pelleting matrix; 5 - pellet cooler

Poly-fractional mixture bulk density was determined according to EN 15103:2009. The point of the method is as follows. Cylindrical capacity with volume of $5 \mathrm{~L}$ was filled with the poly-fractional mixture and weighed. Bulk density was detrmined from the netto weight and the cylinder volume. An electronic scales QILIVE Q-5635 was used, range 0-5000 g; resolution $1 \mathrm{~g}$. Volume of the measuring cylinder was calculated according to GOST 32987.

Moisture content of the poly-fractional mixture was defined according to EN 14774-2:2009. Quantity of chopped straw with known weight was dried in a drying oven at $105 \pm 2{ }^{\circ} \mathrm{C}$ until its 
weight was no longer changing. Equipment: drying oven ShSU-M, $t_{\max }=130^{\circ} \mathrm{C}$; digital laboratory scales NE-100 range 0-100 g, resolution $0.01 \mathrm{~g}$. Relative error of an indirect measurements of the bulk density and moisture content was calculated according to Student's t-distribution [18].

Duration of the laboratory study is $160 \mathrm{~min}$. The first $80 \mathrm{~min}$ are dedicated directly for the experiment; the last 80min are for mathematical analysis of the experimental data and for building surfaces of respond. Students are obligatory instructed about labour safety and all activities are held under supervision from the teacher.

As soon as the program of following laboratory studies is about producing producer gas from biofuels, based on the poly-fractional mixture of chopped straw in a downdraft gasifier, then investigation of the physical and mechanical properties of the abovementioned fuels is performed with accordance to the gasifier's process features $[8 ; 12]$.

At start, students recieve from the teacher a poly-fractional mixtures of chopped wheat straw with known content of fine fractions. Mixture composition is expressed in content of fine fraction (length $<25 \mathrm{~mm}$ ) in percents. Mixture I - content of fine fraction $20 \%$; mixture II - fine fraction content $35 \%$ and mixture III - fine fraction content $50 \%$. The range of fine fraction content is chosen to provide such porousity of the mixture that provides running all reactions of the gasifying process with proper velocity and within defined time intervals, according to filtration and reduction theories [19]. Next, students define the moisture content $W^{P}$ of every mixture according to EN 14774-2:2009. It should be 10, 20 and $30 \%$. If the raw material has different moisture content, then it is dried to the needed level. Then the poly-fractional mixture is compacted in the experimental equipment, Fig. 1.

A multifactor experiment is done to determine the characteristics of connection between the independent factors $\left(R_{f}, W^{P}, k\right)$ and the dependent $(\rho)$, and to find a mathematical equation to describe this connection. Experimental results from every stage of investigation are registerd in laboratory log.

Factor variation intervals are: fine fraction content in the poly-fractional mixture of chopped wheat straw $R_{f}-20,35$ and $50 \%$; moisture content of the poly-fractional mixture of chopped wheat straw $W^{P}-10,20$ and $30 \%$; the coefficient of compaction $k-1.0,1.2,1.4$. Factor encoding: $R_{f}=X_{1}$, $W^{P}=X_{2}, k=X_{3}$. Variation levels of the abovementioned factors are given in Table 1.

Table 1

Variable factors and limits of their variation for definition of material bulk density

\begin{tabular}{|c|c|c|c|}
\hline $\begin{array}{c}\text { Factor variation } \\
\text { level }\end{array}$ & $\begin{array}{c}\text { Fine fraction content in } \\
\text { mixture } \boldsymbol{R}_{\boldsymbol{f}}, \boldsymbol{\%}\end{array}$ & $\begin{array}{c}\text { Moisture content of } \\
\text { mixture } \boldsymbol{W}^{\boldsymbol{P}}, \boldsymbol{\%}\end{array}$ & $\begin{array}{c}\text { Coefficient of } \\
\text { compaction } \boldsymbol{k}\end{array}$ \\
\hline Upper level (+) & 50 & 30 & 1.4 \\
\hline Middle level (0) & 35 & 20 & 1.2 \\
\hline Lower level (-) & 20 & 10 & 1.0 \\
\hline
\end{tabular}

To reduce the number of experiments and obtain the regression equation, the mathematical method of the experiment planning, based on Box-Behnken quadric plan, was used [18]. The planning stage included the following steps. First of all, the factor encoding and scheduling were done, using statistical methods of randomization. The next step was implementation plan of the experiment. Testing of reproducibility of the experiments was done obligatory. The regression coefficients were calculated. The next step was assessment of the significance of regression coefficients and then - the test model adequacy check [18].

According to the plan of the multifactor experiment, the values of the model relative error are lower than $2.8 \%$ [18]. This is the case for all experiments. The values of mean relative deviation are lower than $1.8 \%$ [18]. Thus, the relative error value is less than $10 \%$ [18]. Such relative error value is considered acceptable in modelling. Therefore, it can be concluded that the presented model predicts the bulk density of the poly-fractional mixture with high accuracy.

\section{Results and discussion}

As a result of laboratory experiments and statistical computation, a data array of the polyfractional mixture bulk density was received, see Table 2 . The experimental results were processed using the software "Statistica". 
The Cochrane criterion was used to test the homogeneity of variances. The tabulated value of Cochrane criterion was $G^{\text {tabl }}=0.3346$ at a $5 \%$ level of significance for the number of degrees of freedom $f_{2}=2$ and number of experiments $f_{1}=15$. We received that $G^{\text {com }}=0.198<G^{\text {tabl }}(0.05 ; 15$; $2)=0.334$, therefore the process is reproduced.

The Student test was used to determine the confidence intervals for regression coefficients. The tabulated value of the Student coefficient at a $5 \%$ level of significance for the number of degrees of freedom $f_{2}=2$ and the number of experiments $f_{1}=15$ was $t=4.3$ [18].

The significance of regression coefficients was tested according to the established confidence intervals and covariance. Adequacy test of hypotheses of the obtained regression equation was performed by the Fisher criterion. The estimated value of the Fisher criterion in the dispersion of inadequacy $S_{\text {inadeq }}^{2}=0.242$ was $F^{\text {com }}=4.07$. Since, $F^{\text {com }}=4.07<F^{\text {tabl }}\left(0.05 ; f_{1} ; f_{2}\right)=19.38$, the hypothesis of the adequacy of the regression equation is confirmed.

Planning matrix of multifactor experiment

Table 2

\begin{tabular}{|c|c|c|c|c|c|c|c|c|c|c|}
\hline \multirow{2}{*}{ No } & \multicolumn{3}{|c|}{$\begin{array}{c}\text { Experiment } \\
\text { planning method }\end{array}$} & \multicolumn{4}{|c|}{ Experiments results } & \multicolumn{3}{|c|}{ Model adequacy check } \\
\cline { 2 - 12 } & $X_{1}$ & $X_{2}$ & $X_{3}$ & $\rho_{1}$ & $\rho_{2}$ & $\rho_{3}$ & $\rho_{\text {med }}$ & $\rho_{\text {med.com }}$ & $\begin{array}{c}\left(\rho_{\text {med }}-\right. \\
\left.\rho_{\text {med.com }}\right)\end{array}$ & $\begin{array}{c}\left(\rho_{\text {med }}-\right. \\
\left.\rho_{\text {med.com }}\right)^{2}\end{array}$ \\
\hline 1 & + & + & 0 & 237.4 & 238.2 & 238.4 & 238.0 & 237.46 & 0.54 & 0.29 \\
\hline 2 & + & - & 0 & 198.5 & 199.2 & 199.6 & 199.1 & 198.29 & 0.81 & 0.66 \\
\hline 3 & - & + & 0 & 187.1 & 185.7 & 185.4 & 186.1 & 186.91 & -0.81 & 0.66 \\
\hline 4 & - & - & 0 & 155.6 & 153.8 & 155.7 & 155.0 & 155.54 & -0.54 & 0.29 \\
\hline 5 & 0 & 0 & 0 & 185.5 & 186.3 & 187.0 & 186.3 & 186.53 & -0.23 & 0.05 \\
\hline 6 & + & 0 & + & 250.1 & 251.2 & 251.4 & 250.9 & 250.31 & 0.59 & 0.35 \\
\hline 7 & + & 0 & - & 178.3 & 179.1 & 180.2 & 179.2 & 178.79 & 0.41 & 0.17 \\
\hline 8 & - & 0 & + & 195.8 & 195.3 & 194.9 & 195.3 & 195.71 & -0.41 & 0.17 \\
\hline 9 & - & 0 & - & 139.2 & 139.5 & 139.9 & 139.5 & 140.09 & -0.59 & 0.35 \\
\hline 10 & 0 & 0 & 0 & 186.8 & 186.6 & 186.2 & 186.5 & 186.53 & -0.03 & 0.01 \\
\hline 11 & 0 & + & + & 241.9 & 242.8 & 241.9 & 242.2 & 242.63 & -0.43 & 0.18 \\
\hline 12 & 0 & + & - & 174.5 & 173.0 & 171.5 & 173.0 & 173.25 & -0.25 & 0.06 \\
\hline 13 & 0 & - & + & 202.1 & 201.5 & 201.8 & 201.8 & 201.55 & 0.25 & 0.06 \\
\hline 14 & 0 & - & - & 143.9 & 144.1 & 144.5 & 144.2 & 143.78 & 0.42 & 0.18 \\
\hline 15 & 0 & 0 & 0 & 185.8 & 186.5 & 188.1 & 186.8 & 186.53 & 0.27 & 0.07 \\
\hline
\end{tabular}

Regression coefficients: $b_{0}=186.53 ; b_{1}=23.33 ; b_{2}=17.64 ; b_{3}=31.79 ; b_{12}=1.95 ; b_{13}=3.98$; $b_{23}=2.9 ; b_{11}=4.47 ; b_{22}=3.54 ; b_{33}=0.22$.

After calculating the coefficients of the regression equation, their significance was estimated.

After elimination of the abovementioned coefficients, the polynomial equation got the form:

$$
\begin{aligned}
& \rho=186.53+23.33 \cdot R_{f}+17.64 \cdot W^{p}+31.79 \cdot k+1.95 \cdot R_{f} \cdot W^{P}+ \\
& +3.98 \cdot R_{f} \cdot k+2.9 \cdot W^{p} \cdot k+4.47 \cdot R_{f}^{2}+3.54 \cdot\left(W^{p}\right)^{2}+0.22 \cdot k^{2},
\end{aligned}
$$

where: $\rho$-bulk density of the poly-fractional mixture from chopped wheat straw, $\mathrm{kg} \cdot \mathrm{m}^{-3}$;

$R_{f}$ - fine fraction content in the poly-fractional mixture from chopped wheat straw, \%;

$W^{P}$ - moisture content of the poly-fractional mixture, $\%$;

$k$ - coefficient of compaction.

The coefficient of determination is $R^{2}=0.98$. Graphical representations of the abovementioned equation are given in Fig. 2-4.

According to equation 1 , raising $R_{f}, W^{P}$ and $k$ leads to increasing of the bulk density $\rho$. The coefficient of compaction $k$ makes the biggest impact on the bulk density, somewhat less influensive is the fine fraction content $R_{f}$, and the moisture content $W^{P}$ makes the least impact. 


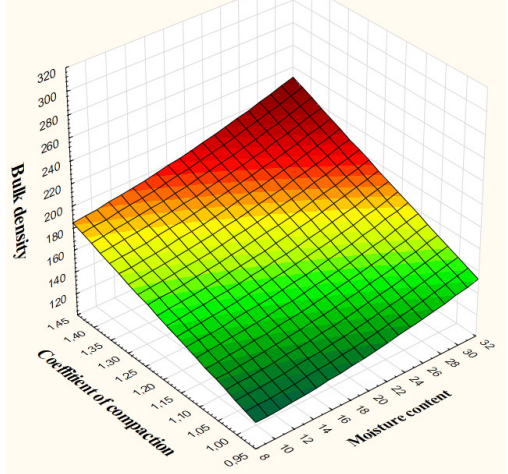

$a$

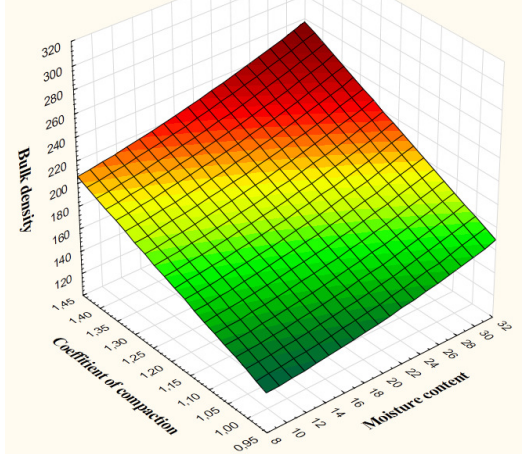

$b$

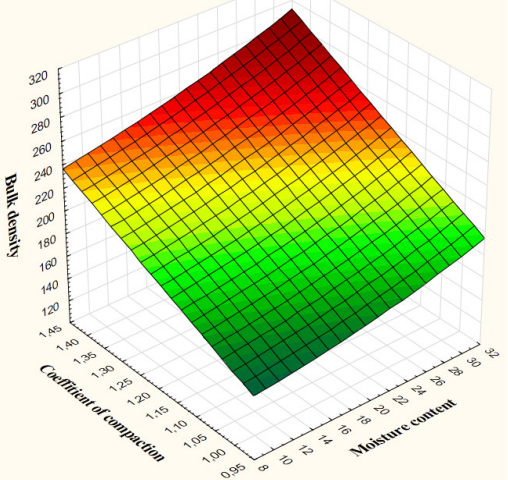

C

Fig. 2. Dependence of chopped wheat straw bulk density $\rho$ on its moisture content $W^{P}$ and coeffitient of compaction $\boldsymbol{k}$ for fine fraction content in mixture $\boldsymbol{R}_{f}: a-R_{f}=20 \% ; b-R_{f}=35 \%$; $c-R_{f}=50 \%$

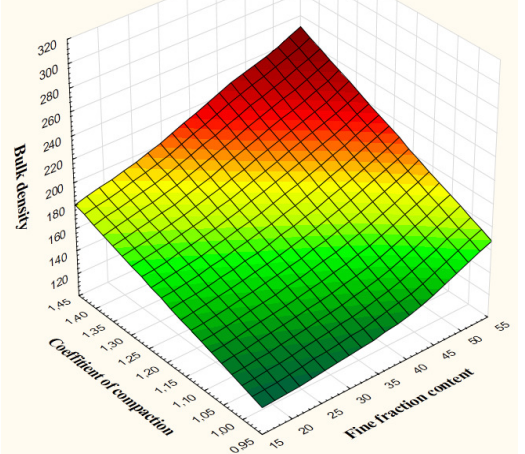

$a$

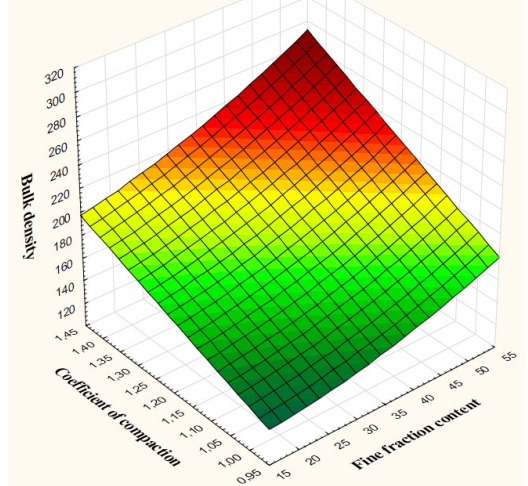

$b$

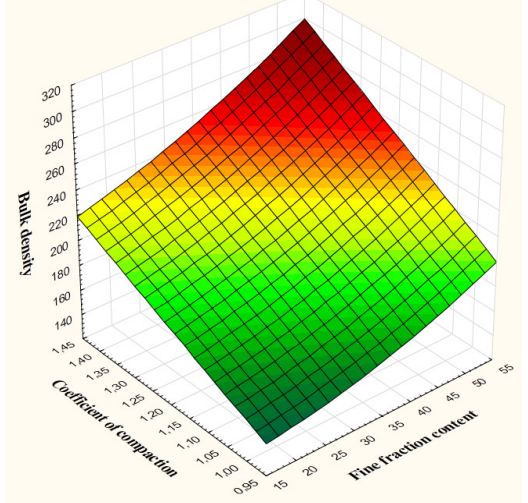

$c$

Fig. 3. Dependence of chopped wheat straw bulk density $\rho$ on its coefficient of compaction $k$, fine fraction content in mixture $\boldsymbol{R}_{f}$ for moisture content $\boldsymbol{W}: a-W^{P}=10 \% ; b-W^{P}=20 \% ; c-$ $W^{P}=35 \%$

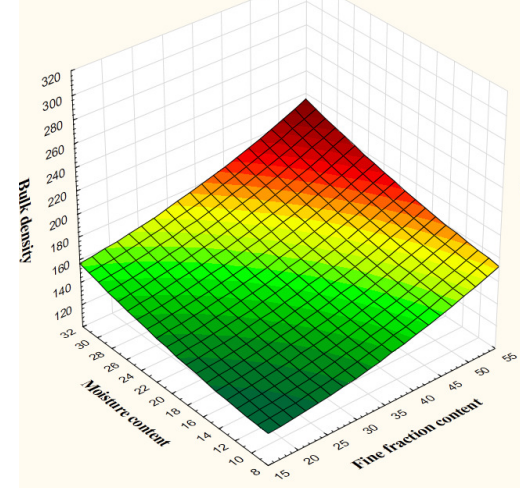

$a$

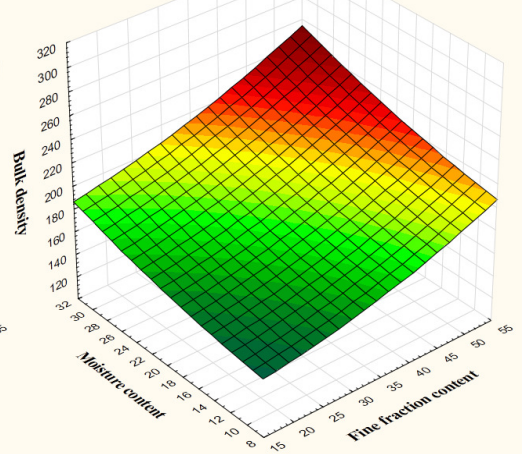

$b$

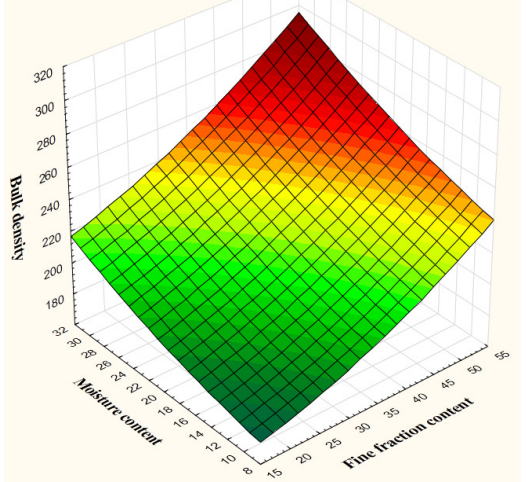

C

Fig. 4. Dependence of chopped wheat straw bulk density $\rho$ on its moisture content $W^{P}$ and fine fraction content in mixture $\boldsymbol{R}_{f}$ for coefficient of compaction $\boldsymbol{k}: a-k=1 ; b-k=1.2 ; c-k=1.4$

According to the dependencies in Fig. 2, at stable fine fraction content in the mixture $R_{f}$ raising the moisture content $W^{P}$ leads to increasing of the bulk density of the chopped straw mixture $\rho$.

As it was prognosed, increasing the coefficient of compaction $k$ raises the bulk density $\rho$. Linear nature of this dependency is explained, because the coefficient of compaction was introduced exactly as a linear parameter. According to Fig. 2, the influence of the moisture content $W^{P}$ on the bulk density $\rho$ is somewhat lower compared to the coefficient of compaction $k$. For example, raising the moisture 
content from 8 to $30 \%$, increases $\rho$ by $6-8 \%$, that is an evidence of such negative factor as high content of ballast in fuel.

The aim of this laboratory study is to determine such values of the fine fracture content $R_{f}$ and the corresponding values of the moisture content $W^{P}$ and the coefficient of compaction $k$, that provide the bulk density $\rho \approx 200-250 \mathrm{~kg} \cdot \mathrm{m}^{-3}$ and the porousity coefficient of the fine grained layer between $\varepsilon=0.54-0.61$ [20]. These conditions are provided at $R_{f}=50 \%, k=1.4$ and $W^{P}=20 \%$.

According to Fig. 3, at stable moisture content $W^{P}$, rasing the coefficient of compaction $k$ and fine fraction content $R_{f}$ in the poly-fractional mixture, leads to increasing of the bulk density $\rho$. The influence of the fine fraction content $R_{f}$ in the mixture on bulk density $\rho$ is nonlinear. The fine fracture content $R_{f}$ in the mixture influences the bulk density $\rho$ less than the coefficient of compaction $k$.

Let us look at the results from the point of further laboratory studies, namely, production of energy from biofuels based on the poly-fractional mixture by means of its direct burning or gasification. To provide the best conditions for heat and mass exchange processes in the fuel layer we use a material with the parameters $R_{f}=50 \%, W^{P}<20 \%$ with the coefficient of compaction $k=1.4$ [21]. Usage of chopped straw with the moisture content $W^{P}>30 \%$ results in violation of heat and mass exchange processes in the active zones of thermotechnical equipment $[8 ; 16]$. A phenomenon of ash-slag agglomeration with the combustion zone localization is observed that is also proved by investigations [12].

According to Fig.4, for stable values of the coefficient of compaction $k$, rising of the moisture content $W^{P}$ and fine fracture content $R_{f}$ in the mixture, at the same time and separately as well, results in increasing of the bulk density $\rho$. At $R_{f}<20 \%$ and moisture content $W^{P}<10 \%$, there is an area, where the bulk density $\rho$ merely changes. This is a typical extrapolation error.

From the results in Fig. 2-4, there is a conclusion that when producing energy from the polyfractional mixture of chopped straw and providing proper energy efficiency of thermotechnical equipment dependent on the moisture content of the raw material $W^{P}$ and fine fracture content $R_{f}$, we have to choose such coefficient of compaction $k$, which provides normal conditions for heat and mass processes in the fuel layer. The results received by students during laboratory studies show that for the moisture content $W^{P}=20-22 \%$ the coefficient of compaction should be within the range $k=1.1-1.25$.

The aim of this investigation was to check the results received by other scientists on defying the bulk density of different plant raw materials and the influence on this parameter on the physical and chemical properties. As well as to find, if it is possible to make a laboratory study that students can perform in 160min. It is found that our results correlate with the data from predecessors $[16 ; 19-21]$. Later it was proved that performing this laboratory study is possible in the laboratory of the Department of Tractors, Vehicles and Bioenergy Systems of the National University of Life and Environmental Sciences of Ukraine (NULES), and also at the Department of Mechanics and Engineering of Agroecosystems of the Zhytomyr National Agroecological University (ZNAEU). Therefore, the practice with the title "Defining the bulk density of fine dispersed plant materials" was prepared and tested at teaching.

\section{Conclusions}

The experimental study and numerical simulations of the bulk density of poly-fractional plant materials have led to the following conclusions. The aim was to verify the published investigations in literature sourses and to get data for the laboratory study preparation for the students of the engineering faculties of ZNAEU and NULES of Ukraine.

1. By means of multifactor experiments the influence of the fine fraction content, moisture content and the coefficient of compaction of a poly-fractional mixture from chopped wheat straw on its bulk density was defined. It was found that raising $R_{f}, W^{P}$ and $k$, leads to increasing of the bulk density $\rho$. The coefficient of compaction $k$ makes the biggest impact on the bulk density.

2. It was found that at $R_{f}=50 \%, k=1.4$ and $W^{P}<20 \%$ the bulk density is $\rho \approx 200-250 \mathrm{~kg} \cdot \mathrm{m}^{-3}$. For that bulk density value the porousity coefficient is $\varepsilon=0.54-0.61$, that provides the best conditions for heat and mass exchange processes in energy production from poly-fractional mixtures of chopped wheat straw. 
3. It should be admitted that the results received by students in laboratory studies correlate with the results published by other authors. Using the obtained results the new laboratory study was prepared and successfully tested for the students of the subjects "Designing and calculation of technological systems in horticulture", "Machines and equipment for biotechnologies" and "Methodology and technology of scientific investigations".

\section{References}

[1] Golub G., Kukharets S., Yarosh Y. etc. Integrated use of bioenergy conversion technologies in agroecosystems. INMATEH - Agricultural Engineering, vol. 51, No. 1, 2017, pp. 93-100.

[2] Ryabchenko O., Golub G., Turčeková N. etc. Sustainable business modeling of circular agriculture production: Case study of circular bioeconomy. Journal of Security and Sustainability, vol. 7, No. 2, 2017, pp. 301-309. DOI: 10.9770/jssi.2017.7.2(10).

[3] Відновлювана енергетика в аграрному виробництві : навч. посіб./За ред. Скидана О. В., Голуба Г. А. (Renewable energy in agricultural production : tutorial/edited by Skydan O., Golub G.). Kyiv: NULES of Ukraine, 2018, 338 p. (In Ukrainian).

[4] Holubenko A., Tsyvenkova N., Nezdvetskaya I., Pluzhnikov O. The results of investigation of corrosion processes in gasifyer when gasifying fuels containing straw and lignin. Proceedings of International conference "Engineering for rural development 2019", May 22-24, 2019, Jelgava, Latvia, pp. 1415-1422.

[5] Голуб Г. А., Кухарець С. М., Чуба В. В., Марус О. А. Виробництво і використання біопалив в агроекосистемах. Механіко-технологічні основи: монографія (Biofuels production and use in agroecosystems. Mechanical and technological fundamentals: monograph). Kyiv: NULES of Ukraine, 2018, 254 p. (In Ukrainian).

[6] Golub G., Marus O., Chuba V., Pavlenko M. Research of the hydro-mechanical mixer parameters for diesel biofuel production with using box-benghken experiment plan. Agricultural Engineering International: CIGR Journal, vol. 21, No. 4, 2019, pp. 121-131.

[7] Голуб Г., Чуба В., Марус О. Визначення витрати палива машинно-тракторним агрегатом при польових випробуваннях (Determination of fuel consumption by machine-tractor unit during the field tests). Науковий вісник НУБіП України. Серія: техніка та енергетика АПК. Vol. 224, 2015, pp. 257-261.

[8] Кухарець С. М., Голуб Г. А., Медведський О. В., Лозовий А. С. Напрямки використання біогазових установок в умовах аграрного виробництва (Directions of biogas plants use in the conditions of agricultural production). Proceedings of the I Ukrainian Scientific and Practical Conference "Bio-energy systems in agrarian production", November 16-17, 2017, Zhytomyr: ZNAEU, Ukraine, pp. 4-11.

[9] Kukharets S., Tsyvenkova N., Yarosh Ya. etc. The results of study into the effect of air-steam blast on the low-grade fuel gasification process. Eastern-European Journal of Enterprise Technologies, vol. 6, No. 8(96), 2018, pp. 86-96.

[10]Голуб Г., Чуба В. Експлуатаційні параметри роботи двигуна при застосуванні дизельного біопалива (Engine performance when using diesel biofuels). Науковий вісник НУБіП України. Серія «Техніка та енергетика АПК», vol. 196, No. 1, 2014, pp. 23-31.

[11] Golub G., Kukharets S., Tsyvenkova N., etc. Research on a boiler furnace module effectiveness working on small fracture wastes. INMATEH - Agricultural Engineering, vol. 55, No. 2, 2018, pp. 9-18.

[12] Golub G., Kukharets S., Tsyvenkova N. etc. Experimental study into the influence of straw content in fuel on parameters of generator gas. Eastern-European Journal of Enterprise Technologies, vol. 5, No. 8, 2018, pp. 76-86. DOI: 10.15587/1729-4061.2018.142159

[13]Проектування машин і обладнання в біоенергетиці (Design of machines and equipment in bioenergy) https://elearn.nubip.edu.ua/course/view.php?id=1270 (In Ukrainian).

[14] Malmgren A., Riley G. Biomass power generation. Comprehensive Renewable Energy, vol. 5, 2012, pp. 27-53.

[15] Yarosh Y., Golub G., Kukharets S. etc. Experimental study of wood gas-operated power plant operation. Proceedings of International conference "Engineering for rural development 2019", May 22-24, 2019, Jelgava, Latvia, pp. 1337-1343. 
[16] Mac an Bhaird S., Walsh E., Hemmingway P. etc. Analysis of bed agglomeration during gasification of wheat straw in a bubbling fluidised bed gasifier using mullite as bed material. Powder Technology, vol. 254, 2014, pp. 448-459. DOI: 10.1016/j.powtec.2014.01.049

[17]Zolotovs'ka O., Kharytonov M., Onyshchenko O. Agricultural residues gasification, dependency of main operational parameters of the process on feedstock characteristics. INMATEH Agricultural Engineering, vol. 50, Issue 3, 2016, pp. 119-126.

[18] Мельников С.В., Ацелкин В.Р., Рощин П.М. Планирование эксперимента в исследованиях сельскохозяйственных процессов (An experiment planning in researches of agricultural processes). Leningrad: Kolos, 1980, 168 p. (In Russian).

[19] Basu P. Biomass gasification, pyrolysis and torrefaction: practical design and theory. Elsevier, 2013. 548 p. Available at: DOI: 10.1016/c2011-0-07564-6

[20] Мезин И.С. Транспортные газогенераторы (Automotive gas producers). Moskow: Ogiz Selhozgiz, 1948, 311 p. (In Russian).

[21] Barmina I., Valdmanis R., Zake M., etc. Development of gasification/combustion characteristics at thermo-chemical conversion of biomass mixtures. Proceedings of International conference "Engineering for rural development 2017", May 24-26, 2017, Jelgava, Latvia, pp. 54-59. [online] [24.05.2017]. Available at: http://tf.llu.lv/conference/proceedings2017/Papers/N011.pdf 